\title{
Kendala Perbankan dalam Meningkatkan Kapasitas Koperasi melalui Pola Joint Financing
}

\section{Banking Problems in Increasing Cooperative Capacity Through Joint Financing Patterns}

\author{
Nisabilah Anjani*, Tarsisius Murwadji \& Bambang Daru Nugroho \\ Program Studi Ilmu Hukum, Fakultas Hukum, Universitas Padjadjaran, Indonesia
}

Diterima: 20 Januari 2020; Disetujui: Mei 2020; Dipublish: 2 Juni 2020

*Coresponding Email: nisabilahanjani98@gmail.com

\begin{abstract}
Abstrak
Tulisan ini bertujuan untuk mengembangkan metode joint financing antara bank dengan koperasi yang mana koperasi di globalisasi ini terlihat semakin tertinggal dikarenakan permasalahan modal yang tidak kunjung selesai serta sistemnya yang masih tradisionil pada saat perkembangan dunia yang semakin modern ini. Oleh karena itu, pemerintah membuat peraturan untuk mengatasi permasalahan ini dengan cara membuat Linkage Program. Masalah difokuskan pada hubungan kerja sama di tahap joint financing sebagai salah satu model dari Linkage program, antara Koperasi Peternak Bandung Selatan dengan BPR Bandung Kidul terdapat berbagai permasalahan dalam mencapai hubungan kerja sama yang adil dan berkepastian hukum. Metode yang digunakan dalam penulisan ini adalah analisis yuridis normatif dengan metode penulisan deskriptif analitis. Kajian ini menyimpulkan bahwa kendalakendala yang menghambat hubungan Joint financing yaitu salah satunya ialah kepemilikan mayoritas saham oleh koperasi yang dapat mencederai prinsip kehati-hatian dan good corporate governance bank. Kedua, dalam hubungan Joint financing antara koperasi dengan bank dalam praktiknya tidak dilaksanakan perjanjian yang mana dapat mengakibatkan terjadinya campur tangan bisnis oleh kedua belah pihak.
\end{abstract}

Kata Kunci: Koperasi, Perbankan, Joint financing.

\begin{abstract}
This paper aims to develop a joint financing method between banks and cooperatives in which cooperatives in globalization look increasingly lagging behind due to unfinished capital problems and a system that is still traditional at a time of increasingly modern world developments. Therefore, the government made regulations to overcome this problem by creating a Linkage Program. The problem is focused on the cooperative relationship at the Joint financing stage as one of the models of the Linkage program, between South Bandung Farmers Cooperatives with BPR Bandung Kidul. There are various problems in achieving fair and legal cooperation. The method used in this research is normative juridical analysis with descriptive analytical writing methods. This study concludes that the obstacles that hamper the Joint financing relationship, one of which is the ownership of majority shares by cooperatives that can harm the principle of prudence and good corporate governance of the bank. Secondly, in the joint financing relationship between cooperatives and banks in practice no agreements were carried out which could result in business interference by both parties.
\end{abstract}

Keywords: Cooperative, Banking, Joint financing.

How to Cite: Anjani, N. Murwadji, T. \& Nugroho, B.D (2020). Kendala Perbankan Dalam Meningkatkan Kapasitas Koperasi Melalui Pola Joint Financing, Jurnal Ilmiah Penegakan Hukum, 7 (1) 2020: 17-26 


\section{PENDAHULUAN}

Koperasi adalah bagian dari tata susunan ekonomi yang menandakan bahwa dalam kegiatannya koperasi turut serta dalam mengambil bagian bagi tercapainya kehidupan ekonomi yang sejahtera, baik untuk anggota perkumpulan itu sendiri maupun untuk masyarakat yang ada di sekitarnya (Fanny dan Hasyim, 2018).

Koperasi yang berlandaskan asas kekeluargaan, memiliki tujuan untuk secara khusus memajukan kesejahteraan anggota dan secara umum masyarakat sekitarnya serta ikut membangun tatanan perekonomian nasional. (Hadhikusuma, 2002).

Koperasi sebagai soko guru perekonomian Indonesia atau pilar perekonomian berdasarkan Pasal 33 ayat (1) Undang-Undang Dasar 1945 diharapkan berperan aktif dalam mewujudkan kesejahteraan dan kemakmuran rakyat, oleh karena itu pun Pemerintah Indonesia mempunyai kepentingan tersendiri atas pertumbuhan dan perkembangan koperasi yang ada di Indonesia.

Bidang kegiatan dan usaha yang dilakukan koperasi adalah bidang pemenuhan kebutuhan bersama para anggotanya, (Trisnawani, 2009) maka sering kali koperasi dihadapkan dengan permasalahan kelemahan dalam segi permodalan atau sumber dananya yang terbatas sebab modalnya hanya mengandalkan iuran anggotanya saja.

Pada era ini, koperasi dianggap kurang terpercaya sebab sistemnya yang masih tradisionil pada saat perkembangan dunia yang semakin modern yang secara langsung mempengaruhi citra koperasi dalam perkembangannya padahal koperasi harus bisa memiliki perkembangan berkepanjangan atau continuous improvement untuk dapat bertahan hidup.

Koperasi juga kerap kali dihadapkan dengan permasalahan rendahnya kualitas sumber daya manusia (SDM) yang bekerja pada sektor UMKM, baik dari segi pendidikan formal maupun pengetahuan dan keterampilan. Hal ini berpengaruh kepada manajemen atas pengelolaan rendahnya gaji dan upah. Umumnya UMKM tumbuh secara tradisional, kurangnya akses pemasaran ke pasar yang potensial (Mulyati, 2016).

Pemerintah membuat Peraturan Menteri Negara Koperasi dan Usaha Kecil dan Menengah Republik Indonesia Nomor 03/Per/M.KUKM/III/2009 tentang Pedoman umum Linkage program antara Bank Umum dengan koperasi (Permen Koperasi No. 3/2009) sebagai bentuk dukungan pemerintah sekaligus solusi atas hambatan yang terjadi pada Koperasi dan Usaha Mikro dan Kecil (UMK).

Keberadaan program ini untuk mengatasi kendala permodalan bagi UMK, perlu dilakukan upaya peningkatkan dan perluasan akses permodalan melalui peningkatan sinergi antara Bank Umum dan Koperasi. Kemampuan koperasi yang dapat menjangkau lapisan masyarakat menengah ke bawah sebenarnya dapat dimanfaatkan juga sebagai modal kerjasama dengan lembaga-lembaga keuangan lainnya, termasuk bank. Kerjasama yang dimaksud ialah kerjasama menyalurkan dana lembaga keuangan kepada anggota koperasi (Murwadji dan Hagi, 2017).

Linkage program disediakan untuk mendukung perkembangan Koperasi yang pada saat ini terlihat tertinggal yang dapat membuat citra koperasi terbantu dengan nama baik bank di masyarakat. Masyarakat perekonomian rendah yang sukar mengakses bank dengan bunga yang relatif besar dapat mengakses dan memanfaatkan lembaga keuangan secara optimal lewat koperasi yang berasaskan kekeluargaan dengan bunga yang relatif kecil.

Fungsi bank tersendiri sebagai lembaga intermediasi dalam penyaluran kredit, mempunyai peran penting bagi dinamika roda perekonomian secara 
keseluruhan serta memfasilitasi pertumbuhan ekonomi. Pada level mikro ekonomi, bank merupakan sumber paling utama pembiayaan bagi para pengusaha. (Ibrahim, 2004)

Bank merupakan Agent of Trust yaitu sebagai lembaga perantara yang dipercaya untuk melayani segala kebutuhan dari dan untuk masyarakat. Bank juga merupakan Agent of Development yaitu sebagai lembaga perantara yang bisa mendorong kemajuan pembangunan melalui fasilitas pembiayaan dengan kemudahan pembayarannya serta penarikan dalam proses transaksi bagi pelaku ekonomi khususnya UMKM (Arifin, 2013).

UMKM apabila tidak diberdayakan akan menyebabkan jurang kemiskinan yang semakin besar yang mana secara langsung mempengaruhi likuiditas bankbank yang hidup sehingga akan menciptakan beban negara sebab angka kriminalitas akibat pengangguran semakin besar. Bank pada dasarnya mempunyai obligasi hukum untuk membantu kendala UMKM dalam hal ini Koperasi untuk dan atas kebaikannya sendiri.

Pihak Bank dalam mempertimbangkan permohonan kredit terlebih dahulu melakukan analisis the five $C$ 's sebagai suatu penerapan dari prinsip kehati-hatian bank sebelum memberikan persetujuan atas permohonan kredit dari calon nasabah. Dalam praktiknya untuk mengamankan kredit yang diberikan kepada nasabah, terutama pemberian kredit kepada golongan ekonomi menengah ke bawah lebih menitikberatkan pada faktor collateral (agunan) yang pada poin ini tidak cocok dengan kondisi mayoritas UMKM pada khususnya (Mulyati, 2016).

Linkage program mempunyai tiga urutan pelaksanaan yaitu channeling, executing dan Joint financing / joint capital. Peneliti memfokuskan pada pola ketiga pada penelitian ini yaitu pola Joint financing namun tidak secara formal, melainkan secara informal.
Secara esensi, Joint financing adalah pembiayaan bersama oleh Bank dan Koperasi terhadap anggota koperasi yang mana resiko pemberian kredit kepada anggota koperasi ditanggung oleh bank dan koperasi sesuai dengan porsi pembiayaan masing-masing pihak yang disepakati sebelumnya.

Adapun yang menjadi objek penelitian pada penulisan ini ialah Koperasi Pertenak Sapi Bandung Selatan (KPBS) yang merupakan koperasi yang sudah maju dan telah melewati pola channeling serta executing, akan tetapi tidak dapat berkembang secara cepat. Keberadaan pola Joint financing ini diharapkan akan mengembangkan koperasi pada bidang pengembangan produk, pelayanan serta jaringan sehingga koperasi dapat bersaing ditingkat global.

Guna meningkatkan kapasitas koperasi menghadapi era globalisasi dan mengembangkan usaha para peternak agar lebih maju maka KPBS menilai perlu adanya suatu jasa perbankan. Didirikanlah Bank Perkreditan Rakyat (BPR) Bandung Kidul sebagai solusi permasalahan yang dihadapi KPBS, dengan 99\% kepemilikan saham oleh KPBS, sehingga keuntungan akan jadi milik anggota.

Permasalahan yang pada umumnya sering dihadapkan ialah walaupun koperasi sudah dapat mandiri akan tetapi koperasi belum bisa mengimbangi kinerja bank. Kendala-kendala serta solusinya perlu ditelaah kembali sebab hal tersebut penting untuk merubah cara pandang bisnis yang masih tradisionil menjadi cara pandang bisnis yang modern dengan dukungan kemajuan teknologi.

Pada pelaksanaanya, setelah KPBS mendirikan BPR Bandung Kidul, KPBS dan BPR tidak bekerjasama menyalurkan kredit kepada anggotanya, melainkan pemberian kredit berjalan hanya melalui BPR Bandung Kidul kepada anggota Koperasi KPBS saja. Kedudukan Koperasi (KPBS) merupakan sebagai pemilik dari Bank (BPR) oleh karena itu hubungan yang 
terjadi antara BPR Bandung Kidul dengan Koperasi KPBS berbeda dengan yang lain dikarenakan BPR Bandung Kidul dijadikan salah satu unit dari Koperasi KPBS tersebut.

KPBS pada dasarnya melaksanakan Linkage program pola Joint financing dengan BPR Bandung Kidul secara informal yang menghendaki Bank dan Koperasi bekerjasama memberikan kredit secara bersama-sama dan menanggung resiko kreditnya pun juga secara bersamasama namun apabila menimbang hubungan antara KPBS dan BPR Bandung Kidul ini yang posisinya ialah BPR sebagai salah satu unit usaha permodalan Koperasi, potensi terjadinya pencederaan terhadap prinsip kehati-hatian dan Good Corporate Governance pada BPR besar terjadi sebab keberadaan hubungan Koperasi yang dapat mengintervensi bank melalui kepemilikan saham BPR sebesar 99\%.

KPBS mengalami kendala internal saat KPBS masih mengelola unit simpan pinjam yaitu anggota merasa tidak harus membayar pinjamannya karena dipengaruhi oleh rasa kepemilikan anggota, oleh karena itu KPBS membuat BPR Bandung Kidul agar dapat meneruskan unit simpan pinjam dengan kewenangan yang lebih besar yaitu kewenangan sebagai bank.

Dalam hubungan kerja antara BPR dengan KPBS ini tidak didasarkan oleh perjanjian yang merinci antara kedudukan BPR dengan KPBS, melainkan hanya sertifikat pemegang saham saja. Kedua belah pihak tidak memiliki perjanjian yang secara rigid mengatur mengenai hak dan kewajiban atau kedudukan kedua belah pihak melainkan hanya ada perjanjianperjanjian mengenai perjanjian simpan pinjam perjanjian pinjaman modal terhadap bank serta perjanjian inventarisasi alat-alat kebutuhan di Koperasi. Keadaan ini dapat mengakibatkan campur tangan antara bank dengan koperasi yang berpotensi saling mencederai hak dan kewenangan masing-masing pihak.

Untuk dapat mengatasi kendalakendala yang ada terhadap KPBS dengan BPR Bandung Kidul baik Koperasi Artha Sejahtera dengan Bank Bukopin Cirebon perlu ditelaah lagi kendala koperasi yang mendasari alasannya untuk mendirikan bank dan memilih metode Joint financing serta bagaimana mewujudkan Joint financing secara informal antara bank dengan koperasi yang adil dan berkepastian hukum.

\section{METODE PENELITIAN}

Penelitian ini menggunakan metode pendekatan yuridis normatif. Pendekatan yuridis normatif yaitu suatu metode yang mana hukum dikonsepsikan sebagai norma, kaidah, asas, dan dogma-dogma, (Komaruddin, 2009) disamping itu juga berusaha menelaah kaidah-kaidah hukum yang berlaku di masyarakat. (Soemitro, 1990).

Teori dan konsep yang berhubungan dengan permasalahan fakta hukum dilapangan yang ada seperti halnya konsep joint financing dengan prinsip kehatihatian bank serta good corporate governance dengan sumber data yang diperoleh melalui wawancara terkait Linkage program pola Joint financing pada KPBS Pangalengan dengan Bank BPR Bandung Kidul serta Koperasi Artha Sejahtera dengan Bank Bukopin Cirebon yang dikaitkan dengan kaidah-kaidah hukum. Hal tersebut bertujuan untuk meneliti penerapan aspek-aspek hukum dalam tanggung jawab bisnis, pelaksanaan koperasi simpan pinjam, pelaksanaan linkage program khususnya pola Joint financing.

\section{HASIL DAN PEMBAHASAN \\ Kendala Hukum Yang Dihadapi Koperasi Yang Mendirikan Bank dan Melakukan Metode Joint financing}

Berdirinya BPR Bandung Kidul didasari dengan permasalahan internal 
dalam keanggotaan KPBS Pangalengan. Pada saat KPBS Pangalengan masih memiliki unit usaha simpan pinjam, terjadi kredit macet dikarenakan anggota yang tidak memiliki kesadaran untuk membayar pinjaman yang dibuat. Anggota cenderung tidak memiliki kesadaran untuk membayar pinjamannya pada koperasi karena dipengaruhi oleh rasa kepemilikannya terhadap koperasi. Dibuatlah BPR Bandung Kidul sebagai solusi berjalannya unit usaha simpan pinjam serta sebagai lembaga pendanaan untuk KPBS Pangalengan.

Pemahaman mengenai konsep kepemilikan bersama koperasi menimbulkan efek perilaku yang semenamena terhadap koperasi oleh anggotanya sebab merasa secara egois, koperasi miliknya tanpa memperhitungkan dampak dari perilaku anggota yang dihadapi oleh koperasi. Dalam hubungan ini, khususnya hubungan dalam Unit Simpan Pinjam Koperasi, revolusi mental mengenai permasalahan ini perlu dibenahi, sebab apabila tidak, koperasi akan sulit berkembang.

Pemahaman ini merupakan hal yang dasar dalam pembangunan sebuah koperasi, yang seharusnya konsep kepemilikan bersama ini diimbangi juga dengan asas gotong royong koperasi yang menyatakan bahwa setiap anggota koperasi harus mempunyai sebuah toleransi, tidak egois atau individualis serta mau dalam bekerja sama dengan anggota lainnya demi memajukan kegiatan usaha koperasi, kesadaran pribadi tersebut serta satu sama lainnya harus saling mempererat. (Kartasapoetra, 2005)

Koperasi yang mengalami permasalahan ini memerlukan lembaga formal lain yakni untuk mencapai profesionalitas dari para anggota, dibutuhkanlah lembaga perbankan sebagai lembaga yang memiliki misi dan fungsi sebagai agen agent of development (Imaniyati, 2010) yang dapat mengatasi permasalahan ini sehingga anggota dapat mengerti hak dan kewajibannya.

Melihat kedudukan KPBS dengan BPR Bandung Kidul, terdapat masalah yang berakar dari kepemilikan saham sebesar 99\% oleh KPBS terhadap BPR Bandung Kidul. Kepemilikan saham 99\% ini memicu adanya tindakan tidak adil atau diskriminasi yang dilakukan bank terhadap umum dengan anggota koperasi. Dirundingkan melalui Rapat Anggota Tahunan dan disampaikan melalui Rapat Umum Pemegang Saham bahwa anggota KPBS yang melakukan simpan pinjam dikenakan bunga hanya sebesar 18\%.

Mengutip dari Susidarto dalam tulisannya Reposisi Pengawasan Bank, perilaku para pengelola dan pemilik bank yang cenderung mengeksploitasi dan mengabaikan suatu prinsip kehati-hatian bank dalam berusaha adalah salah satu faktor yang membuat sistem perbankan nasional menjadi keropos. Disamping menjanjikan keuntungan yang besar jika dikelola secara baik dan prudent, bisnis perbankan merupakan bisnis yang penuh akan resiko. Merupakan bisnis yang penuh akan resiko (full risk business) sebab aktivitasnya sebagian besar mengandalkan dana milik masyarakat, baik dalam bentuk tabungan, giro maupun deposito. (Hermansyah, 2013)

Sehingga hal ini akan menciptakan ketidakseimbangan itu sendiri di dalam RUPS yang mana dapat membuat anggota koperasi berperilaku semena-mena terhadap bank dan dapat berakibat mencederai prinsip kehati-hatian bank. Guna mewujudkan sistem perbankan yang sehat, kuat dan kokoh sangat penting menerapkan prinsip kehati-hatian bank. Hal ini mengingat kebijakan di bidang perbankan ini berperan penting dalam memelihara kestabilan ekonomi secara makro melalui keterlibatannya dengan efektivitas kebijakan moneter.

Dalam Undang-Undang Perbankan disebutkan bahwasanya bank wajib menjalankan usaha sesuai dengan prinsip 
kehati-hatian. Dalam pengertian, bank wajib untuk tetap senantiasa memelihara tingkat kesehatan bank, kecukupan modal, kualitas asset, kualitas manajemen, likuiditas, rentabilitas dan aspek lain yang berhubungan dengan usaha bank.

Prinsip kehati-hatian sebagai upaya untuk meminimalisi setiap resiko yang timbul dari kegiatan usaha bank, (Hanun, 2008) menghendaki kewajiban bagi bank untuk dapat menyediakan informasi tentang kemungkinan timbulnya suatu resiko kerugian sehubungan dengan transaksi nasabah yang dilakukan melalui bank (Pasal 29). Ketentuan ini menunjukan bahwa bank benar-benar memiliki tanggungjawab yang besar terhadap para nasabahnya, serta hal ini penting bagi bank dalam rangka menjaga hubungan baik dan berkelanjutan dengan nasabahnya. Hubungan bank dengan nasabahnya bukan hanya sekedar hubungan debitur-kreditur, namun lebih dari itu yaitu sebagai hubungan kepercayaan atau fiduciary relationship.

Berbeda dengan Bank, dalam sistem kerja Koperasi tidak mengenal yang dinamakan prinsip kehati-hatian ini sehingga membuat koperasi tidak peka terhadap resiko-resiko yang dihadapinya. Bank untuk mencapai suatu hubungan yang baik dengan nasabahnya memerlukan pengaplikasian prinsip kehati-hatian ini agar terciptanya transparasi yang akan membuat nasabah mempercayai bank sehingga tercapainya hubungan kepercayaan antara bank dengan nasabahnya, buhan hanya hubungan kreditur dengan debitur semata.

Pola ini berbeda dengan koperasi sebab koperasi dianugerahkan oleh asas kekeluargaan yang menghendaki konsep kepemilikan bersama oleh anggota terhadap koperasi, sehingga asas ini sudah mendorong hubungan koperasi terhadap anggotanya langsung pada tahap hubungan kepercayaan tanpa ada usaha lebih lanjut lagi untuk membuktikan kepercayaan tersebut, seperti halnya analisa resiko.

Perilaku koperasi juga dapat berakibat mencederai prinsip Good Corporate Governance Bank. Bank adalah lembaga intermediasi yang dalam menjalankan kegiatan usahanya memiliki ketergantungan pada dana masyarakat dan kepercayaan baik dari dalam maupun luar negeri. (Budisantoso, 2006). Dalam menjalankan kegiatan usahanya, bank menghadapi berbagai risiko yaitu risiko kredit, risiko pasar, risiko operasional maupun risiko reputasi. (Amanita, 2008). Banyaknya ketentuan yang mengatur serta membimbing sektor perbankan dalam rangka melindungi kepentingan masyarakat, termasuk ketentuan yang mengatur kewajiban untuk memenuhi modal minimum sesuai dengan kondisi masing-masing bank, menjadikan sektor perbankan sebagai sektor yang highly regulated. (Tobing, Arkeman, Sanim, Nuryartono, 2013)

Pengaturan dan implementasi Good Corporate Governance memerlukan komitmen dari top management dan seluruh jajaran organisasi. (Pasya, 2017) Pelaksanaannya dimulai dari penetapan kebijakan dasar (strategic policy) dan kode etik yang harus dipatuhi oleh semua pihak dalam perusahaan. Kepatuhan terhadap kode etik yang diwujudkan dalam kata dan perbuatan adalah faktor penting sebagai landasan penerapan GCG. (Zarkasy, 2008)

Namun faktanya, Koperasi tidak kurang peka terhadap kehadirannya prinsip Good Corporate Governance, sama halnya seperti yang sudah dibahas dalam prinsip kehati-hatian. Salah satu prinsip GCG yang berkolerasi dalam permasalahan hubungan koperasi dengan bank sebagai objek penelitian ini ialah Independensi, bank harus menghindari terjadinya dominasi yang berlebihan atau tidak wajar oleh stakeholder. (Sundari, 2012). Dikarenakan BPR diperuntukan KPBS sebagai Lembaga (unit) pendanaanya, KPBS akan condong memperlakukan BPR 
sebagai unit usaha yang diperuntukan dan dibangun oleh koperasi sehingga mempunyai wewenang untuk mengendalikan unit perusahaanya tersebut padahal bank seharusnya independen. Permasalahan ini juga didorong KPBS sebagai pimpinan sentral induk perusahaan, berhak untuk mengendalikan anak-anak perusahaan dalam mendukung tujuan kolektif perusahaan group sebagai satu kesatuan ekonomi (Sulistiowati, 2010).

Pada dasarnya, GCG merupakan sebuah konsep atau instrumen umum sebagai langkah pembaharuan tidak hanya dalam perusahaan namun juga dalam segala sistem organisasi. Dalam menerapkan good governance maka organisasi ini terkelola oleh sistem, bukan oleh orang atau secara subjektif (Prijambodo, 2012). Pada saat pengelolaan dijalankan oleh sistem maka terwujud keteraturan yang mendasarkan pada aturan, mekanisme dan ketetapanketetapan yang dibuat oleh aturan eksternal dalam hal ini contohnya UndangUndang atau aturan internal yang dalam hal ini contohnya adalah Rapat Anggota Tahunan (RAT). Sehingga dapat memberikan suatu jaminan yang lebih baik terhadap pemanfaatan sumber daya organisasi menjadi lebih efektif. Pada akhirnya organisasi itu mampu mencapai tujuan yang ditetapkan, dan terjaga kesinambungan hidupnya dalam jangka pendek maupun dalam jangka panjang.

Ketidakpekaan koperasi terhadap prinsip kehati-hatian dan prinsip Good Corporate Governance ini menjadikan suatu kendala tersendiri bagi keberhasilan hubungan kerja sama Joint financing antara Bank dengan Koperasi yang secara langsung juga dapat mencederai berbagai kepentingan masing-masing pihak, oleh karena itu perlu adanya pemahaman mengenai pentingnya penerapan prinsip kehati-hatian dan prinsip Good Corporate Governance oleh koperasi.

\section{Upaya Mewujudkan Joint financing Secara Informal antara Bank dengan Koperasi yang Adil dan Berkepastian Hukum.}

Pada praktiknya, dalam hubungan kerja sama antara Koperasi dengan Bank guna tercapainya tahap Joint financing secara informal ini tidak memiliki perjanjian yang mengatur secara rinci kedudukan kedua belah pihak. Dalam hubungan Koperasi Peternak Bandung Selatan dengan Bank Perkreditan Rakyat Bandung Kidul tidak didasari perjanjian kerjasama yang mengatur secara rigid kedudukan dan kewenangan koperasi dengan bank.

Hubungan antara KPBS dengan BPR Bandung Kidul, campur tangan dapat terjadi dikarenakan perikatan yang diwujudkan dalam hubungan kerjasama ini ialah hanya sertifikat saham kepemilikan saja padahal pendirian Bank ini sudah dimaksudkan dari awal sebagai lembaga pendanaan Koperasi.

Perjanjian kerja sama pada hakikatnya untuk mengetahui kemauan dasar dari pihak yang berkontrak bahwa apakah kesepakatan tersebut mempunyai konsekuensi hukum yang mengikat ataukah hanya mempunyai konsekuensi moral (Simanjutak, 2006).

Fungsi kontrak, terutama dalam dunia bisnis, adalah untuk melindungi kepentingan para pihak dalam rangka mengatur hak dan kewajiban, sehingga tercipta kepastian hukum bagi para pihak yang membuatnya. (Susetya, Diantha, Landra, 2018). Sehingga ketidakhadirannya perjanjian kerja sama yang mengandung kepastian hukum dalam mengatur hubungan Joint financing secara rigid dapat mengakibatkan blunder diantara kedua belah pihak, yang mengakibatkan terjadinya campur tangan oleh pihak koperasi terhadap bank atau baik bank terhadap koperasi yang mana dapat mencederai kewenangan, kepentingan dan tujuan masing-masing pihak. 
Pada dasarnya, campur tangan dapat terjadi dikarenakan tidak adanya suatu batasan yang jelas. Apabila batasan dalam suatu hubungan tidak ditetapkan atau diatur maka campur tangan berpotensi besar untuk terjadi dalam suatu hubungan kerja sama khususnya dalam hubungan Joint financing ini.

Dibutuhkan batasan atau kepastian yang jelas yang dapat diwujudkan dalam suatu perjanjian yang disebut sebagai kontrak sebagai upaya mencegah hal itu terjadi. Kontrak secara tegas dimaksudkan sebagai kesepakatan para pihak yang mempunyai konsekuensi hukum yang mengikat. Kontrak sebagai salah satu perwujudan perikatan ini berfungsi mengatur hak dan kewajiban serta batasan-batasan kewenangan para pihak yang dapat menghindarkan dari terjadinya campur tangan kedua belah pihak sebab kontrak memiliki konsekuensi hukum (legal enforceability) apabila tidak dilaksanakan.

Bank sebagai lembaga utama keuangan yang selalu diandalkan dalam perekonomian negara ini seharusnya memiliki peran yang bisa lebih mengarahkan terhadap koperasi guna menghindarkan campur tangan yang dapat terjadi sebab kesetaraan kedudukan yang dibuat oleh hubungan Joint financing ini.

Sebagai lembaga keuangan yang dipercayai negara untuk menunjang pelaksanaan pembangunan nasional dalam rangka meningkatkan pemerataan, pertumbuhan ekonomi dan stabilitas nasional ke arah peningkatan kesejahteraan rakyat banyak membuat bank diatur oleh berbagai regulasi tentang bank dan prinsip hukum seperti halnya prinsip kehati-hatian bank.

Prinsip kehati-hatian (prudent banking principle) menyatakan bahwa bank dalam menjalankan fungsi dan kegiatan usahanya wajib bersikap hati-hati (prudent) dalam rangka melindungi dana masyarakat yang dipercayakan padanya. Prinsip ini juga dapat digunakan sebagai upaya menghindarkannya campur tangan yang dapat terjadi terhadap koperasi dengan bank dalam hubungan Joint financing ini. Dengan berbagai regulasi yang mengatur dan prinsip hukum yang mempengaruhi dan membentuk perkembangan bank, Bank seharusnya mempunyai kemampuan yang lebih besar untuk membina koperasi dalam hubungan Joint financing ini.

\section{SIMPULAN}

Pemahaman mengenai konsep kepemilikan bersama koperasi menimbulkan efek perilaku yang semenamena terhadap koperasi oleh anggotanya sebab kerap secara egois, koperasi miliknya tanpa memperhitungkan dampak dari perilaku anggota yang dihadapi oleh koperasi.

Pemahaman ini merupakan hal yang dasar dan umum dalam kendala pembangunan sebuah koperasi, yang seharusnya konsep kepemilikan bersama ini diimbangi juga dengan asas gotong royong koperasi yang menyatakan bahwa setiap anggota koperasi harus memiliki sebuah toleransi dengan tidak egois atau individualis serta memiliki kemauan dalam bekerja sama dengan demi memajukan kegiatan usaha koperasi.

Kendala yang menjadi permasalahan untuk dihadapi oleh Koperasi yang mendirikan suatu Bank yaitu kepemilikan saham yang terlalu besar dapat menciptakan ketidakseimbangan dalam Rapat Umum Pemegang Saham Bank yang secara langsung juga dapat mencederai prinsip kehati-hatian bank serta Good Corporate Governance bank.

Campur tangan bisnis juga dapat terjadi dikarenakan dalam melaksanakan Joint financing antara koperasi dan bank tidak didasari perjanjian kerjasama yang mengatur secara rigid kedudukan dan kewenangan koperasi dengan bank, hal ini dapat mengakibatkan terjadinya blunder serta dapat mencederai kewenangan, 
kepentingan dan tujuan masing-masing pihak.

Dibutuhkan kontrak sebagai salah satu perwujudan perikatan ini yang berfungsi mengatur hak dan kewajiban serta batasan-batasan kewenangan para pihak yang dapat menghindarkan dari terjadinya campur tangan oleh kedua belah pihak sebab kontrak memiliki konsekuensi hukum apabila tidak dilaksanakan.

Penting juga adanya untuk menempatkan posisi Bank selaku lembaga yang membina koperasi guna mencegah terjadinya campur tangan. Dengan berbagai regulasi yang mengatur dan prinsip hukum yang mempengaruhi dan membentuk perkembangan bank, Bank mempunyai kemampuan yang lebih besar untuk membina koperasi dalam hubungan Joint financing ini.

\section{DAFTAR PUSTAKA}

Amalia, E. (2009). Keadilan Distributif dalam Islam: Penguatan peran LKM dan UKM di Indonesia. Jakarta: Raja Grafindo Persada.

Arifin, J. (2013). Hubungan Hukum Kemitraan Dalam Linkage Program Perbankan Syari'ah. Jurnal Ekonomi Islam, 4(2):4354.

Budisantoso, Totok \& Triandaru, S. (2006). Bank dan Lembaga Keuangan Lain. Jakarta: Salemba Empat.

Hadhikusuma, R.T.S.R. (2002). Hukum Koperasi Indonesia. Jakarta: Raja Grafindo.

Hanun, N. (2008). Penerapan Manajemen Resiko Hukum di Bidang Perkreditan Perbankan. Skripsi. Universitas Indonesia.

Hermansyah. (2014) Hukum Perbankan Nasional Indonesia. Jakarta: Kencana Prenada Media Group.

Ibrahim, J. (2004). Bank Sebagai Lembaga Intermediasi dalam Hukum Positif. Bandung: Utomo.

Imaniyati, N.S. (2010). Pengantar Hukum Perbankan Indonesia. Bandung: Refika Aditama.

Kartasapoetra, G. (2005). Praktek Pengelolaan Koperasi. Jakarta: Rineka Cipta.

Komaruddin. (1982). Ekonomi Perusahaan dan Manajemen. Jakarta: Alumni.

Mulyati, E. (2016). Kredit Perbankan: Aspek Hukum dan Pengembangan Usaha Mikro
Kecil dalam Pembangunan Perekonomian Indonesia. Bandung: Refika Aditama.

Murwadji, T. \& Robby, A.H. (2017). Edukasi dan Penyehatan Koperasi Melalui Lingkage Program Perbankan. Padjadjaran Jurnal Ilmu Hukum, 4(3): 454-472.

Pasya, N. (2017). Penerapan Good Corporate Governance Pada Manajemen Operasional, Manajemen Risiko, Kepatuhan Syariah dan Dampaknya Terhadap Kinerja Bank BTN Syariah. Tesis. Universitas Islam Negeri.

Peraturan Menteri Negara Koperasi dan Usaha Kecil dan Menengah Republik Indonesia Nomor 03/Per/M.KUKM/III/2009 tentang Pedoman umum Linkage program

Prijambodo, (2012). Tata Kelola Yang Baik Pada Koperasi (Good Governance Cooperative) Satu Kebutuhan Peningkatan Kualitas SDM Koperasi. Widiaiswara Kementrian Koperasi dan UKM.

Simanjutak, R. (2006). Teknik Perancangan Kontrak Bisnis. Jakarta: Kontan.

Sitepu, F.S. \& Hasyim. (2018). Perkembangan Ekonomi Koperasi di Indonesial. Jurnal Niagawan. 7(2): 59-68.

Soemitro, R.H. (1990). Metodologi Penelitian Hukum dan Jurimentri. Jakarta: Ghafia Indonesia.

Sugiyono. (2008). Metode Penelitian Bisnis (Pendekatan Kuantitatif, Kualitatif, dan R\&D). Bandung: Alfabeta.

Sulistiowati. (2010). Aspek Hukum dan Realitas Bisnis Perusahaan Grup di Indonesia. Jakarta: Erlangga.

Sundari, H. (2012). Evaluasi Penerapan Good Corporate Governance Pada Bank PD BPR Sarimadu. Jurnal Sorot, 9(1): 43-58.

Susetya, I.G.P.H., Diantha, I.M.P. \& Landra, P.T.C. (2018). Adaptasi Doktrin Promissory Estopel dalam Penyelesaian Ganti Rugi Pada Tahap Pra Kontrak Pada Hukum Kontrak di Indonesia. Jurnal Ilmiah Prodi Magister Kenotariatan. 3(1): 105-121.

Tobing, A. Arkeman, Y. Sanim, B. \& Nuryartono, R.N. (2013). Pengaruh Penerapan Good Corporate Governance Terhadap Tingkat Kesehatan dan Daya Saing di Perbankan Indonesia. Jurnal Manajemen Teknologi. 12(3): 298-318

Trisnawani, T. (2009). Akuntansi Untuk Koperasi dan UKM. Jakarta: Salemba Empat.

Undang-Undang Nomor 25 Tahun 1992 tentang Perkoperasian

Undang-Undang Nomor 7 Tahun 1992 jo Undang-Undang Nomor 10 Tahun 1998 tentang Perbankan 
Nisabilah Anjani, Tarsisius Murwadji \& Bambang Daru Nugroho, Kendala Perbankan dalam Meningkatkan

Yushita, A.N. (2008). Implementasi Risk Management Pada Industri Perbankan Nasional. Jurnal Pendidikan Akutansi Indonesia. 6(1): 75-86.
Zarkasy, W. (2008). Good Corporate Governance, Pada Perusahaan Manufaktur, Perbankan dan Jasa Keuangan Lainnya. Bandung: Alfabeta. 